\title{
Frequency of time overrun causes in road construction in Palestine: Contractors' View
}

\author{
Ibrahim Mahamid \\ Construction Engineering and \\ Management, Hail University \\ Civil Engineering Department \\ Hail, Saudi Arabia \\ imahamid@ymail.com
}

TIME, COST AND QUALITY HAVE THEIR PROVEN IMPORTANCE AS THE PRIME MEASURES FOR PROJECT SUCCESS. However, the history of the construction industry worldwide is full of projects that were completed with significant time and cost overruns. This study is conducted to investigate the occurrence frequency of time overrun causes in road construction projects in the West Bank in Palestine from contractors' viewpoint through a questionnaire survey. The field survey included 34 contractors. 52 factors affecting time overrun were identified during the research. The survey concluded that the top ten frequent factors are: segmentation of the West Bank and limited movement between areas,

\section{Keywords}

Delay, Time overrun, Frequency, Road Construction, Contractors, Palestine political situation, progress payments delay by owner, lack of equipment efficiency, difficulties in financing project by contractor, personal conflicts among labors, poor communication by consultant with other construction parties, conflict between contractor and other parties, award project to lowest bid price, unreasonable project time frame by the owner. 


\section{INTRODUCTION}

The construction industry has its own characteristics that distinguish it from other sectors of the economy. It is fragmented, sensitive to changing variables such as political and environmental factors, and has a significantly high rate of business failure (Nega, 2008).

The golden triangle (cost, time, and quality) is used to measure the project performance and success. Generally, the success of a project is defined by accomplishing it within specified cost, time and quality. However, the construction industry is full of projects that were completed with significant time and cost overruns (Amhel et al., 2010). According to Faridi et al. (2006) delays have an adverse impact on project success in terms of time, cost, quality and safety. The effects of construction delays are not confined to the construction industry only, but influence the overall economy of a country.

For the purpose of this research, time overrun is defined as the time difference between the actual completion time and the estimated completion time, agreed by and between the client and the contractor during signing of the contract.

In Palestine, the local construction industry is one of the main economic driving sectors, supporting the Palestinian national economy. It contributes to $26 \%$ of the Palestinian GDP (MAP, 2002). This is a relatively high proportion covered by this sector comparing to what is mentioned by Chitkara (2004) in that construction industry accounts 6-9 \% of GDP in many countries. However, many local construction projects report poor performance due to many causes such as (UNRWA 2006, cited in Enshassi, 2009):

$\checkmark$ unavailability of materials

- excessive amendments of design and drawings

> poor coordination among participants

> ineffective monitoring and feedback lack of project leadership skills
Mahamid and Bruland (2012) concluded that $100 \%$ of road construction projects implemented in the West Bank suffering from time overrun, therefore a study to identify the causes affecting time overrun in road construction projects is necessary in order to reduce or control this phenomenon. This study is conducted to investigate the frequency of occurrence of time overrun causes in road construction in the West Bank in Palestine from contractors' viewpoint.

\section{Objectives of the study}

The main objectives of this study include the followings:

$\checkmark$ To identify the factors affecting time overruns in road construction projects in the West Bank

> To identify the frequency of occurrence of the factors affecting time overrun from contractors' perspective

> To suggest some measures against the risk factors of time overrun based on the study findings.

\section{Literature review}

Many studies have been conducted to identify the factors affecting time overrun in construction projects. Mahamid (2011) indicated that the most severe factors affecting time delay in road construction projects in the West Bank in Palestine from the owner perspective are: poor communication between construction parties, poor resource management, delay in commencement, insufficient inspectors, and rework.

Al-Najjar (2008) concluded that the top affecting factors that cause time overrun in building construction projects in Gaza Strip as perceived by contractors are: strikes, Israeli attacks and border closures, lack of materials in markets, shortage of construction materials at site, delay of material delivery to site, cash problem during construction, poor site management, poor economic conditions (currency, inflation rate, etc), shortage of equipment at site, equipments and tool shortage on site, and owner delay in freeing the contractor financial payments.

Odeh and Battaineh (2002) found that contractors and consultants agreed that owner interference, inadequate contractor experience, financing and payments, labor productivity, slow decision making, improper planning, and subcontractors are among the top ten most important factors of construction delay in Jordan.

Al-Momani (2000) investigated causes of delay in 130 public building projects constructed in Jordan during the period of 1990-1997. He presented regression models of the relationship between actual and planned project duration for different types of building facilities. He concluded that the main causes of delay are related to designer, user changes, weather, site conditions, late deliveries, economic conditions and increase in quantity.

Assaf and Al-Hejji (2006) discussed the delay in large construction project in Saudi Arabia. Seventy-three factors affecting time overrun were identified during the research. They concluded that the most common factor of delay identified by the contractors, the consultants and the owners is "change order".

Koushki et al. (2005) conducted a study in Kuwait to study the causes of time and cost overrun in construction projects. A person-interview survey of 450 randomly selected private residential project owners and developers have been done. They concluded that the main causes of delays are changing orders, owners' financial constraints, and owners' lack of experience. They stated the following recommendation to the owners in order to minimize time delays: (1) project owners should require the availability of adequate funds, (2) allocation of sufficient time and money at the design phase, (3) selection of a competent consultants and reliable contractor to carry out the work.

Asnaashari et al. (2009) presented the result of an investigation into the main factors which cause construction 
delay in Iran. The results reveal that most of construction projects in Iran are subject to delay. Cash constraints, shortage of resources, high inflation rate, delay in payments, and disputes in the supply chain are the top causes of delay in the Iranian construction industry.

Faridi and El-Sayegh (2006) studied the delay in construction projects in UAE and concluded that $50 \%$ of the construction projects encounter delays and are not completed on time. The top significant causes of construction delays are approval of drawings, inadequate early planning and slowness of the owners' decision-making process.

Mezher and Tawil (1998) conducted a survey of the factors affecting time overruns in the construction industry in Lebanon from the viewpoint of owners, contractors and architectural/engineering firms. It was found that owners had more concerns with regard to financial issues; contractors regarded contractual relationships the most important, while consultants considered project management issues to be the most important factors affecting time overruns.

Aibinu et al. (2002) studied and evaluated the effects of construction delays on project delivery in Nigerian construction industry. They found that the six effects of construction delay are: time overrun, cost overrun, dispute, arbitration and litigation and total abandonment.

The delay of any construction project affects the direct costs of the project. In the case where the project is a public building or facility, the complications increase as the client is a government organization. The effects of delay in such cases may include (Al-Kharashi and Skitmore, 2009):

$\checkmark$ confusion regarding the public development plans

> disturbance of the budget execution plan for the government authority involved

- public inconvenience resulting from delay of the project.

\section{Main group Factors under each group}

award project to lowest bid price

disturbance to public activities

1. Project
group

limited construction area

inconvenient site access

poor ground condition

poor soil quality

poor terrain condition

progress payments delay by owner

delays in decision making by owner

poor communication by owner with other construction parties

unreasonable project time frame

2. Owner financial status of owner
group

delay in approving sample materials

undefined scope of working

late land hand-over by owner

change orders by owner during construction

late issuing of approval documents by owner

\section{Materials and equipments group}

4. Labors
group

5. External group

6. Design
group

7. Contractor
group

sroup

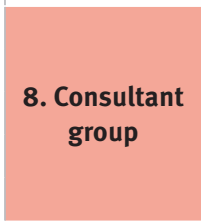

lack of equipment efficiency

shortage in equipments

changes in material types and specifications during construction

shortage in construction material

low productivity of labors

low level of equipment-operator's skill

insufficient labors

personal conflict between labors and management team

personal conflicts among labors

segmentation of the West Bank and limited movement between areas

political situation

exchange rate fluctuation

changing of bankers policy for loans

weather condition

monopoly

natural disaster

late design works

mistake in design

inappropriate design

difficulties in financing project by contractor

poor communication by contractor with other construction parties

conflict between contractor and other parties

poor resource management

rework due to errors during construction

ineffective scheduling of project by contractor

poor qualification of the contractors' technical staff

delay in commencement

poor site supervision by contractor

improper construction method

inflexibility of consultant

poor communication by consultant with other construction parties

delay in performing inspection by consultant

incapable inspectors

insufficient inspectors

Table 1 List of delay factors and related group 


\begin{tabular}{|l|c|c|}
\hline Factor & $\begin{array}{c}\text { Frequency } \\
\text { index (\%) }\end{array}$ & Rank \\
\hline limited construction area & 44.12 & 2 \\
\hline inconvenient site access & 43.53 & 3 \\
\hline poor ground condition & 34.12 & 4 \\
\hline poor soil quality & 32.35 & 5 \\
\hline
\end{tabular}

Table 2 Ranking of factors under project group

And from the contractor's viewpoint, delay is simply an additional liability as:

$\checkmark$ the construction period becomes longer

$\checkmark$ the longer period results in higher overhead costs and expenses

$\checkmark$ the entire contractor's working capital may become trapped in one project.

\section{Research methodology}

This research is based on a survey designed to gather all necessary information in an effective way. The survey presents 52 factors generated on the basis of related research work on construction delay, together with input, revision and modifications by some construction parties (Table 1). A questionnaire was developed in order to evaluate the frequency of occurrence of the identified factors.

The studied target population includes contractors who hold valid registration from the Palestinian Contractors Union in road specialization within the West Bank. Contractors' information (address, grade, name, etc...) was collected from the Palestinian Contactors Union. Simple random sampling was used to select the participants from an available list. Data were gathered through a survey and analyzed by using the frequency index.

\section{Questionnaire design}

The questionnaire is divided into two main parts. Part I is related to general information for the company. Contractors were further requested to answer questions pertaining to their experience in the road construction industry. Part II includes the list of the identified factors that might affect time overrun in road construction projects. These factors are classified into 8 groups according to the source of delay: project, owner, contractor, consultant, design, labor, material and equipment, and external. For each factor a ques-
Table 3 Ranking of factors under owner group tion was asked: what is the frequency of occurrence of this factor? The frequency was categorized on a five-point scale as follows: always, often, moderate, rarely, and very rarely and (on 5 to 1 point scale).

\section{Data analysis}

The suggested factors are ranked by the measurement of the frequency index. The following formula is used to rank them based on frequency level as identified by the participants.

Frequency Index $(\%)=\Sigma a(n / N) \star 100 / 5$ Eq. (1)

Where, a: the constant expressing weighting given to each response (ranges from 1 for very rarely up to 5 for always). $n$ : the frequency of the responses. $\mathrm{N}$ : the total number of responses.

It should be noticed that number 5 put in the equation (1) since five-point scale is used into frequency categorization of the identified factors. The frequency index for each factor was cal-

\begin{tabular}{|c|c|c|}
\hline Factor & $\begin{array}{l}\text { Frequency } \\
\text { index }(\%)\end{array}$ & Rank \\
\hline progress payments delay by owner & 78.82 & 1 \\
\hline award project to lowest bid price & $63 \cdot 53$ & 2 \\
\hline unreasonable project time frame by the owner & 62.94 & 3 \\
\hline poor communication by owner with other construction parties & 62.35 & 4 \\
\hline financial status of owner & 61.18 & 5 \\
\hline delays in decision making by owner & 57.65 & 6 \\
\hline undefined scope of working & 46.47 & 7 \\
\hline postponement of project by owner & 36.47 & 8 \\
\hline delay in approving sample materials & $34 \cdot 71$ & 9 \\
\hline late issuing of approval documents by owner & $34 \cdot 71$ & 10 \\
\hline late land hand-over by owner & 30.59 & 11 \\
\hline change orders by owner during construction & 28.24 & 12 \\
\hline
\end{tabular}




\begin{tabular}{|c|c|c|}
\hline Factor & $\begin{array}{l}\text { Frequency } \\
\text { index }(\%)\end{array}$ & Rank \\
\hline difficulties in financing project by contractor & 67.65 & 1 \\
\hline conflict between contractor and other parties & 65.29 & 2 \\
\hline poor resource management & 57.06 & 3 \\
\hline poor communication by contractor with other construction parties & 55.88 & 4 \\
\hline rework due to errors during construction & 48.82 & 5 \\
\hline poor qualification of the contractors' technical staff & 44.12 & 6 \\
\hline delay in commencement & 42.35 & 7 \\
\hline ineffective scheduling of project by contractor & $39 \cdot 41$ & 8 \\
\hline poor site supervision by contractor & 35.29 & 9 \\
\hline improper construction method & 31.76 & 10 \\
\hline
\end{tabular}

Table 4 Ranking of factors under contractors group

culated according to Equation (1) from contractors' view. The group index was calculated by using the average of the frequency indexes of the factors under each group.

\section{Research findings and results}

\section{General characteristics of} respondents

The questionnaire was sent out to a total of 40 contractors asking their contribution in ranking the identified 52 factors in terms of frequency using an ordinal scale. A total of 34 contractors filled the questionnaire. The response rate by contractors is $85 \%$. The contractors who are included in the survey have an average of more than 10 years of experience.

\section{Ranking of factors affecting} time overrun

The factors under each group are ranked by the measurement of frequency index according to Equation (1).

\section{Project group}

Table 2 shows the frequency index and ranking of each factor under the project group from the contractors' view. 5 factors are considered under this group.

\begin{tabular}{|l|c|c|}
\hline Factor & $\begin{array}{r}\text { Frequency } \\
\text { index (\%) }\end{array}$ & Rank \\
\hline poor communication by consultant with other construction parties & 67.65 & 1 \\
\hline inflexibility of consultant & 57.65 & 2 \\
\hline delay in performing inspection by consultant & 43.53 & 3 \\
\hline incapable inspectors & 35.88 & 4 \\
\hline insufficient inspectors & 31.18 & 5 \\
\hline
\end{tabular}

Table 5 Ranking of factors under consultants group

The table shows that the top frequent factor under this group is limited construction area. The results show that two factors under this group are of moderate frequency while the other three are rarely occurred.

\section{Owner group}

11 factors are listed under this group. Table 3 shows that the top three frequent factors under this group are: progress payment delay by the owner, award project to lowest bid price, and unreasonable project time frame by the owner.

\section{Contractors group}

10 factors are listed under contractors group. Table 4 shows that the top three frequent factors under this group are: difficulties in financing project by contractor, conflict between contractor and other parties, and poor resource management. The results show that the less frequent factors under this group are: ineffective scheduling of project by contractor, poor site supervision by contractor, and improper construction method.

\section{Consultants group}

Table 5 shows the frequency index and ranking of each factor under the consultants group. 5 factors are identified under this group. The table shows that the most frequent factor is poor communication by consultant with other construction parties.

\section{Design group}

Table 6 shows the frequency index and ranking of each factor under the design group. 3 factors are identified under this group. The table shows that the most frequent factor under this group is late design works.

\section{External group}

7 factors are listed under the external group. Table 7 shows that the top frequent factor is segmentation of the West Bank and limited movement 


\begin{tabular}{|l|c|c|}
\hline Factor & $\begin{array}{r}\text { Frequency } \\
\text { index (\%) }\end{array}$ & Rank \\
\hline late design works & 50.59 & 2 \\
\hline mistake in design & 31.76 & 3 \\
\hline inappropriate design & 29.41 & 3 \\
\hline
\end{tabular}

Table 6 Ranking of factors under design group

\begin{tabular}{|l|c|c|}
\hline $\begin{array}{l}\text { Factor } \\
\begin{array}{l}\text { segmentation of the West Bank and limited } \\
\text { movement between areas }\end{array}\end{array}$ & $\begin{array}{c}\text { Frequency } \\
\text { index (\%) }\end{array}$ & Rank \\
\hline $\begin{array}{l}\text { political situation } \\
\text { changing of bankers policy for loans }\end{array}$ & 82.35 & 3 \\
\hline $\begin{array}{l}\text { exchange rate fluctuation } \\
\text { weather condition }\end{array}$ & 85.00 & 4 \\
\hline disturbance to public activities & 52.94 & 5 \\
\hline monopoly & 50.59 & 6 \\
\hline natural disaster & 41.18 & 8 \\
\hline
\end{tabular}

Table 7 Ranking of factors under external group

Overall factors ranking

The frequency index and ranking of all investigated 52 factors affecting time overrun in road construction projects in the West Bank from contractors' view are listed in Table 10.

The results shows that there are two factors with frequency index above $80 \%$, they are: segmentation of the West Bank and limited movement between areas and political situation. The results also show that only one factor has frequency index above $70 \%$ and less than $80 \%$ that is progress payments delay by owner (frequency index $=78.82 \%$ ).

\section{Top ten frequent factors}

Table 11 illustrates the ranking of the top ten frequent factors affecting time overrun in road construction projects in the West Bank and their related groups from contractors' view. It can be seen that two factors are related to the external group, three to the owner group, two to the contractor group, one to the materials and equipments group, two to the owner group, and one to the labors group. between areas, followed by political situation. The less frequent factors (rarely occurred) under this group are: monopoly and natural disaster.

\section{Labors group}

Table 8 shows the frequency index and ranking of each factor under the labors group. 5 factors are identified under this group. The top three factors under this group are: personal conflicts among labors, low level of equipment-operator's skill, and insufficient labors.

\section{Equipments and materials group}

4 factors are listed under this group. Table 9 shows that the top frequent factor under this group is lack of equipment efficiency, followed by changes in material types and specifications during construction and shortage in equipments respectively.

\begin{tabular}{|l|c|c|}
\hline Factor & $\begin{array}{r}\text { Frequency } \\
\text { index (\%) }\end{array}$ & Rank \\
\hline personal conflicts among labors & 67.65 & 1 \\
\hline low level of equipment-operator's skill & 61.76 & 2 \\
\hline insufficient labors & 61.18 & 3 \\
\hline personal conflict between labors and management team & 54.12 & 4 \\
\hline low productivity of labors & 42.94 & 5 \\
\hline
\end{tabular}

Table 8 Ranking of factors under labors group

\begin{tabular}{|l|c|c|}
\hline Factor & $\begin{array}{c}\text { Frequency } \\
\text { index (\%) }\end{array}$ & Rank \\
\hline lack of equipment effeciency & 68.82 & 1 \\
\hline changes in material types and specifications during construction & 54.71 & 2 \\
\hline shortage in equipments & 51.76 & 3 \\
\hline shortage in construction material & 47.65 & 4 \\
\hline
\end{tabular}

Table 9 Ranking of factors under equipments and materials group 


\section{Groups ranking}

The delay factors are grouped into eight groups. Ranking of these groups associated with frequency of occurrence by contractors is presented in Table 12.

Table 12 shows that the top three groups of delay in road construction projects from contractors' view are: labors (frequency index $=57.53 \%$ ) materials and equipments (frequency index $=55.74 \%$ ) external ( frequency index $=53.01 \%$ )

\section{Discussion of results}

The top five frequent factors affecting time overrun in road construction projects from contractors' view are discussed in the following paragraphs:

1. Segmentation of the West Bank and limited movement between areas Segmentation of the West Bank means dividing the West Bank into many parts, which limits the movement of labors, goods and services between the areas (i.e. cities and villages). The check points between the Palestinian areas which are controlled by Israel may prevent or delay labors, materials, and equipments to arrive the project site on time.

2. Political situation - The political situation in the West Bank is described as unstable because of the conflict between the Palestinian and Israeli. This situation leads to shortage in materials, shortage in equipments, limitations on material import, and limitation on movement which lead to time overrun.

3. Progress payments delay by owner Progress payments are of high importance to contractors in order to fulfill the high daily expenses. Due to the delay of payments by the owner, work progress can be delayed because there is inadequate cash flow to support construction expenses especially for those contractors who are not financially sound. This result is supported by Assaf et al. (2006), Al-

\section{Factor}

segmentation of the West Bank and limited movement between areas

82.35

political situation

80.00

progress payments delay by owner

78.82

3

lack of equipment effeciency

68.82

4

difficulties in financing project by contractor

67.65

5

personal conflicts among labors

67.65

6

poor communication by consultant with other construction parties

67.65

7

conflict between contractor and other parties

65.29

8

award project to lowest bid price

63.53

9

unreasonable project time frame by the owner

62.94

10

poor communication by owner with other construction parties

62.35

11

low level of equipment-operator's skill

61.76

12

financial status of owner

61.18

insufficient labors

61.18

14

delays in decision making by owner

57.65

15

inflexibility of consultant

57.65

poor resource management

57.06

17

poor communication by contractor with other construction parties

55.88

18

changing of bankers policy for loans

55.29

19

changes in material types and specifications

during construction

$54 \cdot 71$

20

personal conflict between labors and management team

54.12

21

exchange rate fluctuation

52.94

22

shortage in equipments

51.76

23

late design works

50.59

24

weather condition

50.59

25

rework due to errors during construction

48.82

26

shortage in construction material

47.65

27 


\begin{tabular}{|c|c|c|}
\hline undefined scope of working & 46.47 & 28 \\
\hline limited construction area & 44.12 & 29 \\
\hline poor qualification of the contractors' technical staff & 44.12 & 30 \\
\hline delay in performing inspection by consultant & 43.53 & 32 \\
\hline inconvenient site access & 43.53 & 31 \\
\hline low productivity of labors & 42.94 & 33 \\
\hline delay in commencement & 42.35 & 34 \\
\hline disturbance to public activities & 41.18 & 35 \\
\hline ineffective scheduling of project by contractor & 39.41 & 36 \\
\hline postponement of project by owner & 36.47 & 37 \\
\hline incapable inspectors & 35.88 & 38 \\
\hline poor site supervision by contractor & 35.29 & 39 \\
\hline delay in approving sample materials & 34.71 & 40 \\
\hline late issuing of approval documents by owner & 34.71 & 41 \\
\hline poor ground condition & 34.12 & 42 \\
\hline monopoly & 33.53 & 43 \\
\hline poor soil quality & 32.35 & 44 \\
\hline improper construction method & 31.76 & 45 \\
\hline mistake in design & 31.76 & 46 \\
\hline insufficient inspectors & 31.18 & 47 \\
\hline late land hand-over by owner & 30.59 & 48 \\
\hline poor terrain condition & 30.00 & 49 \\
\hline inappropriate design & 29.41 & 50 \\
\hline change orders by owner during construction & 28.24 & 51 \\
\hline natural disaster & 28.24 & 52 \\
\hline
\end{tabular}

\section{Table 10 Overall ranking of delay factors}

Najjar (2008), Odeh et al. (2002), Kaliba et al. (2009), and Koushki et al. (2005).

4. Lack of equipment efficiency - The financial status of the contractors and the limitations on importing in the West Bank by Israel lead to difficulties in investing in new equipments, therefore the contractors use old and poorly maintained equipments to do the works. This situation affects the efficiency of the equipments and as a result, it affects the time overrun. This result is in line with Aibinu et al. (2006), Al-Najjar (2008), and Kaliba et al. (2009).

5. Difficulties in financing project by contractor - Many of the contracting firms in the West Bank are small in size and not financially sound, they are highly depending on progress payments to pay the works' expenses. When the payments delay by the owner, the contractor faces difficulties to pay these expenses which may lead him, in many cases, to suspend the works until he get his payments. This result is supported by Asnaashari et al. (2009), Al-Najjar (2008), and Kaliba et al. (2009).

\section{CONCLUSION}

This study is conducted to investigate the factors affecting time overrun in road construction projects in the West Bank in Palestine in order to identify these factors and their frequency of occurrence from contractors' viewpoint. 52 factors affecting time overrun were identified through detailed literature review. The identified factors are combined into eight groups. The field survey included 34 contractors.

The top ten frequent factors affecting time overrun as seen from the contractors' view are:

segmentation of the West Bank and limited movement between areas

$\checkmark$ political situation

> progress payments delay by owner

- lack of equipment efficiency

$\checkmark$ difficulties in financing project by contractor

- personal conflicts among labors

- poor communication by consultant with other construction parties

$\checkmark$ conflict between contractor and other parties

award project to lowest bid price

unreasonable project time frame by the owner 
On the other hand, the bottom ten fac-

tors are:

$>$ monopoly

poor soil quality

$\checkmark$ improper construction method

$>$ mistake in design

$\checkmark$ insufficient inspectors

late land hand-over by owner

$>$ poor terrain condition

\begin{tabular}{|c|c|c|c|}
\hline Factor & $\begin{array}{l}\text { Frequency } \\
\text { index (\%) }\end{array}$ & Rank & Related group \\
\hline $\begin{array}{l}\text { segmentation of the West Bank and } \\
\text { limited movement between areas }\end{array}$ & 82.35 & 1 & external \\
\hline political situation & 80.00 & 2 & external \\
\hline progress payments delay by owner & 78.82 & 3 & owner \\
\hline lack of equipment effeciency & 68.82 & 4 & $\begin{array}{l}\text { materials and } \\
\text { equipments }\end{array}$ \\
\hline $\begin{array}{l}\text { difficulties in financing } \\
\text { project by contractor }\end{array}$ & 67.65 & 5 & contractor \\
\hline personal conflicts among labors & 67.65 & 6 & labors \\
\hline $\begin{array}{l}\text { poor communication by consultant } \\
\text { with other construction parties }\end{array}$ & 67.65 & 7 & consultant \\
\hline $\begin{array}{l}\text { conflict between contractor } \\
\text { and other parties }\end{array}$ & 65.29 & 8 & contractor \\
\hline award project to lowest bid price & 63.53 & 9 & owner \\
\hline $\begin{array}{l}\text { unreasonable project time } \\
\text { frame by the owner }\end{array}$ & 62.94 & 10 & owner \\
\hline
\end{tabular}

Table 11 Top ten frequent factors and their related groups

\begin{tabular}{|l|c|c|}
\hline Group & Frequency index(\%) & Rank \\
\hline labors & 57.53 & 1 \\
\hline materials and equipments & 55.74 & 2 \\
\hline external & 53.01 & 3 \\
\hline owner & 49.80 & 4 \\
\hline contractor & 48.76 & 5 \\
\hline consultant & 47.18 & 6 \\
\hline design & 37.25 & 7 \\
\hline project & 36.82 & 8 \\
\hline
\end{tabular}

Based on the study findings, the following measures against the risk factors are suggested:

Contractors are recommended to have qualified and quantified equipments in order to be able to perform the project with high efficiency.

Contractors are recommended to have enough cash before beginning in any project to avoid the financial problems. They should also monitor financial spending of the project and payments because any problem in financial aspect will lead to time overrun.

Owners are advised not to depend on the lowest price contractor to execute the project. It is advised to award the bid to the most appropriate contractors that are financially and technically sound.

Owners are advised to pay progress payment to the contractor on time because it impairs the contractor's ability to finance the work.

The Government should improve new regulations to the benefit of construction parties because of the unstable political situations and segmentations of the West Bank.

The construction parties should take the external factors into consideration at the time of project scheduling and planning. 


\section{References}

Aibinu, A. and Jagboro, G. (2002). The effects of construction delays on project delivery in Nigerian construction industry. Int. J. Project Manage. 20: 593-599.

Al-Kharashi, A. and Skitmore, M. (2009). Causes of delays in Saudi Arabian public sector construction projects. Construction Management and Economics. 27(1): 3-23.

Al-Momani, A. (2000). Construction delay: a quantitative analysis. Int. J. Project Manage. 18(1): 51-59.

Al-Najjar, J. (2008). Factors influencing time and cost overruns on construction projects in the Gaza Strip. Master thesis, Islamic University, Gaza.

Amehl, O., Soyingbe, A., and Odusami, K. (2010). Significant factors causing cost overruns in telecommunication projects in Nigeria. J. Construction in Developing Countries, Vol. 15.

Assaf, S. and Al-Hejji, S. (2006). Factors affecting time overrun in large construction projects. Int. J. Project Manage. 24: 349-357.

Asnaashari, E., Farahani, S., Hoseini, A., and Knight, A. (2009). Causes of delay in Iranian construction projects. Fifth International Conference on Construction in the 21 st Century (CITC-V) “Collaboration and Integration in Engineering, Management and Technology” May 20-22, 2009, Istanbul, Turkey.

Chitkara, K. (2004). Construction Project Management, Planning, Scheduling, and Controlling, Tata McGraw Hill, 4th edition, India.

Enshassi, A., Mohamed, S., and Abushaban, S. (2009). Factors affecting the performance of construction projects in the Gaza Strip. J. Civil Eng. and Manage. 15(3): 269-280.

Faridi, A. and El-Sayegh, S. (2006). Significant factors causing delay in the UAE construction industry. J. Construction Management and Economics. 24(11): 1167-76.

Kaliba, C., Muya, M., and Mumba, K. (2009). Cost escalation and schedule delays in road construction projects in Zambia. Int. J. Project Manage. 27: 522-531.

Koushki, P., Al-Rashid, K., and Kartam, N. (2005). Delays and cost increases in construction of private residential projects in Kuwait. Construction Management and Economics. 23(3):285-94
Mahamid, I. (2011). Risk Matrix for Factors Affecting Time Delay in Road Construction Projects: Owners' Perspective. Engineering, Construction and Architectural Management, Vol. 18 Iss: 6, pp.609- 617 .

Mahamid, I. and Bruland, A. (2012). Cost deviation in road construction projects: The case of Palestine. Australasian Journal of Construction Economics and Building, Vol 12, No 1 , pp: $58-71$.

MAP. (2002). Survey of the Construction Services Industry. Unpublished mission report. The West Bank and Gaza.

Mezher, T., and Tawil, W. (1998). Factors affecting time overruns in the Construction Industry in Lebanon. J. Engineering Construction and Architecture Management. 24: 251-260.

Nega, F. (2008). Factors and effects of cost overrun on public building construction projects in Ethipia. Master thesis, Addis Ababa University, Addis Ababa, Ethiopia.

Odeh, A. and Battaineh, H. (2002). Factors of construction delay: traditional contracts. Int. J. Project Manage. 20(1): 67-73.

Palestinian Contractors Union. Personal contact in July, 2010, Ramallah, The West Bank, Palestine. 